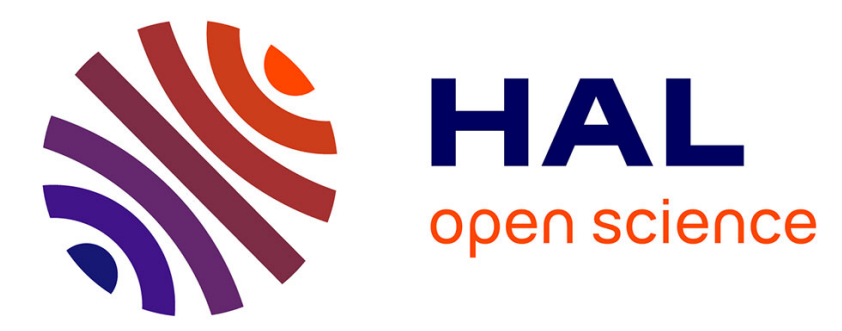

\title{
Reconciling justice and attribution research to advance climate policy
}

Christian Huggel, Ivo Wallimann-Helmer, Daithi Stone, Wolfgang Cramer

\section{To cite this version:}

Christian Huggel, Ivo Wallimann-Helmer, Daithi Stone, Wolfgang Cramer. Reconciling justice and attribution research to advance climate policy. Nature Climate Change, 2016, 6 (10), pp.901-908. 10.1038/NCLIMATE3104 . hal-01444653

\section{HAL Id: hal-01444653 \\ https://hal.science/hal-01444653}

Submitted on 12 Apr 2018

HAL is a multi-disciplinary open access archive for the deposit and dissemination of scientific research documents, whether they are published or not. The documents may come from teaching and research institutions in France or abroad, or from public or private research centers.
L'archive ouverte pluridisciplinaire $\mathbf{H A L}$, est destinée au dépôt et à la diffusion de documents scientifiques de niveau recherche, publiés ou non, émanant des établissements d'enseignement et de recherche français ou étrangers, des laboratoires publics ou privés. 


\section{Title: Reconciling justice and attribution research to advance climate policy} Manuscript NCLIM-15122002

Authors:

Christian Huggel ${ }^{1}$

Ivo Wallimann-Helmer ${ }^{2}$

Dáithí Stone ${ }^{3}$

Wolfgang Cramer ${ }^{4}$

${ }^{1}$ Department of Geography, University of Zurich, Winterthurerstrasse 190, 8057 Zurich, Switzerland, tel: +41 4463551 75, fax: +41 4463568 41, email: christian.huggel@geo.uzh.ch

${ }^{2}$ Program of Advanced Studies in Applied Ethics, Centre for Ethics, University of Zurich, Zollikerstrasse 117, 8008 Zurich, Switzerland, email: wallimann@philos.uzh.ch

${ }^{3}$ Lawrence Berkeley National Laboratory, 1 Cyclotron Road, MS-50F1650, Berkeley, California 94720, USA, email: dstone@lbl.gov

${ }^{3}$ Institut Méditerranéen de Biodiversité et d'Ecologie marine et continentale (IMBE), Aix Marseille Université, CNRS, IRD, Avignon Université, Technopôle Arbois-Méditerranée, Bât. Villemin - BP 80, F13545 Aix-en-Provence cedex 04, France, email : wolfgang.cramer@imbe.fr Correspondence and requests for material/information should be directed to Christian Huggel.

\section{Abstract}

The Paris Climate Agreement is an important step for international climate policy, but the compensation for negative effects of climate change based on clear assignment of responsibilities remains highly debated. Both from a policy and science perspective, it is unclear how responsibilities should be defined and on what evidence base. We explore different normative principles of justice relevant to climate change impacts, and ask how different forms of causal evidence of impacts drawn from detection and attribution research could inform policy approaches in accordance with justice considerations. We reveal a procedural injustice based on the imbalance of observations and knowledge of impacts between developed and developing countries. This type of injustice needs to be considered in policy negotiations and decisions, and efforts be strengthened to reduce it. 
The Paris Agreement ${ }^{1}$ of the United Nations Framework Convention on Climate Change (UNFCCC) is considered an important milestone in international climate policy. Among the most critical points during the Paris negotiations were issues related to climate justice, including the question about responsibilities for the negative impacts of anthropogenic climate change. Many developing countries continued to emphasize the historical responsibility of the developed world. On the other hand, developed countries were not willing to bear the full burden of climate responsibilities, reasons among others being the current high levels of greenhouse gas emissions and substantial financial power of some Parties categorized as developing countries (i.e. Non-Annex I) in the UNFCCC. Many Annex I Parties were particularly uncomfortable with the issue of 'Loss and Damage' (L\&D), which is typically defined as the residual, adverse impacts of climate change beyond what can be addressed by mitigation and adaptation ${ }^{2,3}$. Although L\&D is now anchored in the Paris Agreement in a separate article (Article 8$)^{1}$, questions of responsibility and claims for compensation of negative impacts of climate change basically remain unsolved.

Claims for compensation, occasionally also called climate 'reparations' ${ }^{4}$, raise the question of who is responsible for which negative climate change impacts, how to define such responsibilities and on the basis of what type of evidence. Scientific evidence has become increasingly available from recent studies and assessments, termed "detection and attribution of climate change impacts", revealing numerous discernable impacts of climate change on natural, managed and human systems worldwide ${ }^{5-7}$. In some cases, these impacts have been found to be substantial, but often the effects of multiple non-climatic drivers ('confounders') acting on natural and especially human and managed systems (e.g. land-use change, technical developments) have either been greater than the effect of climate change or have rendered attempts to determine the relative importance thereof difficult. A significant portion of attribution research has focused on the effects of increased atmospheric greenhouse gas concentrations on extreme weather events, yet usually without adopting an impacts perspective $^{8}$. Recent studies have therefore emphasized the need for a more comprehensive attribution framework that considers all components of risk (or L\&D), including vulnerability and exposure of assets and values in addition to climate hazards ${ }^{9}$. Other contributions have discussed the role of attribution analysis for adaptation and L\&D policies ${ }^{10-13}$. How detection and attribution research could inform, or engage with climate policy and justice debates is currently largely unclear. Some first sketches of a justice framework to address the assignment of responsibility for L\&D have recently been developed ${ }^{14,15}$. However, the question of which type of evidence would best cohere with each of the various concepts of justice has not been addressed despite its importance for the achievement of progress in international climate policy. 
1 In this Perspective we explore the different concepts and dimensions of normative justice research

2 relevant to issues of climate change impacts (see Textbox 1). We adopt a normative perspective and

3 analyze how the application of principles of justice can inform respective political and legal contexts.

4 We study the extent to which different forms of scientific evidence on climate change impacts,

5 including detection and attribution research (see Textbox 2), can contribute to, or inform, the

6 respective justice questions and related policy debates. Normative principles of justice define who is

7 morally responsible for an impact and how to fairly distribute the burdens of remedy. In the political

8 and in particular in the legal context liability defines an agent's legal duties in case of unlawful

9 behavior $^{16}$. Liability of an agent for climate change impacts defines a legal duty to pay for remedy of the negative effects. Liability can comprise compensation for L\&D but also, for instance, include 11 fines $^{17,18}$.

In the following we first address questions of liability and compensation and why a potential implementation faces many hurdles on the scientific, political and legal level. We then consider the role that recognition of moral responsibilities for climate change impacts could play in fostering political reconciliation processes. Third, we explore the feasibility of the principle of ability to assist (or pay) and focus on risk management mechanisms as a response to immediate and preventive needs. Finally, we address the uneven distribution of knowledge about impacts across the globe as assessed in the $5^{\text {th }}$ Assessment Report (AR5) of the Intergovernmental Panel on Climate Change (IPCC), and reveal an additional injustice on a procedural level with important further implications for policy and science. 
International climate policy is loaded with moral evaluations. The fact that emissions of greenhouse gases from human activities lead to climate change is not morally blameworthy as such. In order to assess emissions as ethically relevant it is necessary to evaluate their consequences based on normative principles. The level at which climate change is "dangerous" in an ethically significant sense has to be defined. Similarly, normative principles become relevant when differentiating responsibilities in order to deal with the adverse effects of climate change ${ }^{16,19,20}$. In climate policy, as reflected in normative climate justice research, the following principles are relevant for establishing who bears responsibility for climate change impacts and for remedying those impacts:

Polluter-Pays-Principle (PPP): It is commonly accepted that those who have contributed or are contributing more to anthropogenic climate change should shoulder the burdens of minimizing and preventing climate change impacts in proportion to the magnitude of their contribution to the problem. From a PPP perspective, it is not only high-emitting developed countries that are called into responsibility to share the burden and assist low-emitting communities facing climate change risks, but also high-emitting developing countries ${ }^{21-23}$.

Beneficiary-Pays-Principle (BPP): The BPP addresses important ethical challenges emerging from the PPP such as that some people have profited from past emissions, yet have not directly contributed to anthropogenic climate change. The BPP claims that those benefitting from the high emissions of others (e.g. their ancestors or other high-emitting co-citizens) are held responsible to assist those impacted by climate change irrespective of whether they themselves caused these emissions ${ }^{21,24-26}$. Ability-to-Pay-Principle (APP): The PPP and BPP both establish responsibilities irrespective of the capacity of the duty-bearers to contribute to climate change measures or reduce emissions. This can result in detrimental situations for disadvantaged high emitters and beneficiaries, be it individuals or countries. Following the APP only those capable of carrying burdens are responsible to contribute to climate change measures or emission reductions ${ }^{21,23,27}$.

In this Perspective, we deal with the APP under the label of "Ability-to-Assist-Principle" (AAP) in order to broaden the perspective beyond monetary payments toward consideration of assistance with climate change impacts more generally. Furthermore, we do not address the difference between the PPP and the BPP because to a large extent the sets of duty-bearers identified by the two principles overlap. None of the above principles provides any natural guidance on the threshold for emissions in terms of quantity or historical date at which they become a morally relevant contribution to dangerous climate change. 
Scientific evidence that human-induced climate change is impacting natural and humans systems can come in a number of forms, each having different applications and implications ${ }^{28}$. We draw here an analogy to U.S. environmental litigation ${ }^{29}$ where typically two types of causation are relevant: "general causation" refers to the question of whether a substance is capable of causing a particular damage, injury or condition, while "specific causation" refers to a particular substance causing a specific individual's injury.

In the line of general causation, evidence for the potential existence of anthropogenic climate change impacts is relatively abundant (for more examples and references see the main text). Long-term monitoring may, for instance, reveal a trend toward more frequent wildfires in an unpopulated area. These observations may have little to say about the relevance of climate change, or of emissions for that climate change, but they can be useful for highlighting the potential urgency of an issue. Another form of evidence may come from a mechanistic understanding of how a system should respond to some change in its environmental conditions. The ranges of plant and animal species may, for instance, shift polewards in response to an observed or expected warming. In this case, the relevance to human-induced climate change may be explicit, but it remains unclear whether the range shifts have indeed occurred.

In order to be confident that an impact of anthropogenic climate change has indeed occurred, more direct evidence is required, akin to "specific evidence" in U.S. environmental litigation ${ }^{29}$. The most complete set of information for understanding past changes in climate and its impacts, commonly referred to as "detection and attribution", combines observational and mechanistic evidence, by confronting predictions of recent changes based on our mechanistic understanding with observations of long-term variations ${ }^{30}$. These analyses address two questions: the first, detection, examines whether the natural or human system has indeed been affected by anthropogenic climate change, versus changes that may be related to natural climate variability or non-climatic factors. The second, attribution, estimates the magnitude of the effect of anthropogenic climate change as compared to the effect of other factors. These other factors (also termed 'confounders') might be considered external drivers of the observed change (e.g. deforestation driving land-cover changes).

Impacts of multi-decadal trends in climate have now been detected in many different aspects of natural and human systems across the continents and oceans of the planet ${ }^{6}$. Analysis of the relevant climate trends suggests that anthropogenic emissions have played a major role in at least two thirds of the impacts induced by warming, but few of the impacts resulting from precipitation trends can yet be confidently linked to anthropogenic emissions ${ }^{7}$. Overall, research on detection and attribution 
1 of climate change impacts is still emerging and there remain few studies available that demonstrate

2 a causal link between anthropogenic emissions, climate trends and impacts.

3 END TEXT BOX: Evidence that climate change has impacted natural and human systems

4

5 
Compensation of those who suffer harm by those responsible for the harm, and more specifically, responsible for the negative impacts of climate change, represents a legitimate claim from the perspective of normative justice research ${ }^{23,31-33}$. In their most common understanding, principles such as the PPP or BPP provide the justice framework to identify those responsible for climate change impacts and establish a basis for liability and compensation (see Textbox 1). However, issues of compensation have not yet been sufficiently clarified and remain contested in international climate policy. Driven by the pressure exerted by countries such as the U.S. and others, the notion that L\&D involves or provides a basis for liability and compensation has been explicitly excluded in the decisions taken in Paris $2015^{1}$. L\&D has previously been thought to require consideration of causation, as well as the deviations from some (possibly historical) baseline condition ${ }^{34}$. The Paris Agreement and related discussions have not offered any clarity about what type of evidence would be required for claims of liability and compensation to be legitimate, either from a normative mechanisms under international policy. Liability and compensation represent the strongest and most rigid reference frame to clarify who is responsible to remedy climate change impacts, but also involve major challenges, both in terms of policy and science, as we will outline below. Liability and compensation involve clarification of impacts due to climate variability versus anthropogenic climate change, since no one can be morally blamed or held legally liable for negative impacts wholly resulting from natural climate variability ${ }^{21,22,27}$. Accordingly, and as further detailed below, we suggest that here the strongest scientific evidence in line with specific causation is required, i.e. detection and attribution (see Textbox 2).

Figure 1 sketches a detection and attribution framework as it has been developed in recent research ${ }^{30,35}$ and assessments ${ }^{6}$. It reflects the relation of climatic and non-climatic drivers and detected climate change impacts in both natural and human systems at a global scale. As a general guideline, changes in many physical, terrestrial and marine ecosystems are strongly governed by climatic drivers such as regional changes in average or extreme air temperature, precipitation, or ocean water temperature. Due to the high likelihood of a major anthropogenic role in observed trends in these regional climate drivers, there is accordingly potential for high confidence in detection and attribution of related impacts of anthropogenic climate change ${ }^{7}$. The negative impacts of climate change potentially relevant for liability and compensation usually concern human systems, and for these climatic drivers are typically less important than for natural systems: any anthropogenic climate effect can be outweighed by the magnitude of socio-economic changes, for instance considered in terms of exposure and vulnerability (e.g. expansion of exposed 
assets or people, or increasing climate resilient infrastructure). As a consequence, as documented in the IPCC AR5 and subsequent studies ${ }^{6,7}$, there is currently only low confidence in the attribution of a major climate change role in impacts on human systems, except for polar and high mountain regions where livelihood conditions are strongly tied to climatic and cryospheric systems (Fig. 1). In order to establish confidence in the detection of impacts, long-term, reliable, high-quality observations, as well as better process understanding, are crucial for both natural and human systems. Assuming that some substantial level of confidence will be required for issues of liability and compensation, we need to recognize that a very high bar is set by requiring high-quality observations over periods of several decades. Precisely these requirements are likely one of the reasons why studies of detection and attribution of impacts to anthropogenic climate change are still rare.

In the context of liability and compensation a separate pathway to climate policy is being developed in climate litigation under existing laws. In some countries such as the U.S. climate litigation has been used to advance climate policy but so far only a small fraction of lawsuits have been concerned with questions of rights and liabilities as related to damage or tort due to climate change impacts ${ }^{36,37}$. In the U.S. where by far the most such lawsuits are documented worldwide, several cases on imposing monetary penalties or injunctive relief on greenhouse gas emitters have been brought to court but so far, all of them have ultimately failed ${ }^{38}$. One of the most prominent lawsuits is known as California v. General Motors where the State of California claimed monetary compensation from six automakers for damage due to climate change under the tort liability theory of public nuisance. Damages specified for California included reduced snow pack, increased coastal erosion due to rising sea levels, and increased frequency and duration of extreme heat events. As with several other lawsuits, the case was dismissed on the grounds that non-justiciable political questions were raised. Further legal avenues that have been taken and researched with respect to the negative impacts of climate change include human rights in both domestic and international law $34,39,40$. Generally, currently available experiences cannot sufficiently clarify what type of evidence would be needed in court to defend a legal case on climate change liability. However, there is useful precedent from litigation over harm caused by exposure to toxic substance where typically specific causation is required $^{41}$. In our context, hence, this translates into detection and attribution of impacts of anthropogenic climate change.

Overall, experience so far indicates that the hurdles are considerable, and they may range from aspects of justiciability, to the proof required for causation, to the applicability of the no-harm rule established in international law or of the application of extraterritoriality in human rights law la,39,42,43. $^{29}$. Based on these challenges and on the analysis of precedents from cases with harm due to exposure to toxic substances, some scholars favor ex-ante compensation as compared to ex-post 
compensation and refer to experiences with monetary disaster funds used to compensate affected vicitms ${ }^{41}$. It is interesting to note that in one of the very few lawsuits on climate change liability that have been accepted by a court ex-ante compensation is claimed. In this currently ongoing legal case at a German court, a citizen of the city of Huaraz in Peru is suing RWE, a large German energy producer, for their cumulative emissions causing an increased local risk of floods from a glacier lake in the Andes that formed as glaciers receded. Specific causation is likely required for this case but additional difficulty arises from proving the relation of harm of an individual to emissions. From an attribution point of view governments are in a better position to claim compensation than individuals because damages due to climate change can be aggregated over time and space over their territory and/or economic interests ${ }^{44}$.

In conclusion, at the current state of legal practice, political discussions and available scientific evidence, significant progress in terms of liability and compensation seems rather unlikely in the near future. Politically, creating a monetary fund in line with considerations of ex-ante compensation may yet be the most feasible mechanism. In the following, we present two alternative approaches to achieve justice in relation to climate change impacts.

\section{Recognition of responsibilities and reconciliation}

As a first alternative we refer to the notion that legitimate claims of justice may extend beyond questions of liability and compensation, involving instead restorative justice, and more specifically recognition and acknowledgement of moral responsibilities for climate change impacts ${ }^{14}$. Following from that, we argue that recognition of responsibilities would be a first important step in any process of reconciliation.

Reconciliation is often discussed in the context of normative restorative (or transitional) justice research, which typically relates to the aftermath of violence and repression ${ }^{45,46}$. In this context it is argued that recognition of wrongs is important in order to attain and maintain social stability ${ }^{47}$. In the case of the negative effects of climate change, recognition could play a similar role. However, since the most negative effects of climate change will occur at least several decades from now, ex-ante recognition of responsibilities of climate change impacts would be required to support maintaining social stability. Recognition of responsibilities neither is the final step nor does it exclude the possibility of compensation, but we suggest it can represent a fundamental element in the process, especially where recovery has limitations. This is particularly the case when impacts of climate change are irreversible, such as for submersion of low-lying islands, permafrost thawing in the Arctic, or loss of glaciers in mountain regions ${ }^{48-51}$. 
1 On the level of scientific evidence, recognition of responsibilities as a first step in a reconciliation

2 process implies clarification of those who caused, or contributed to, negative impacts of anthropogenic climate change, and of those who suffer the damage and losses. If the goal is a practical first step in a reconciliation process between those generally contributing to and those generally being impacted by climate change, rather than experiencing a specific impact, then we argue that basic understanding of causation (i.e. general causation) could provide sufficient evidence. Understanding of general causation (see Textbox 2) can rely on multiple lines of evidence collected from observations, modeling or physical understanding, but not all are necessarily required and nor do they all have to concern the exact impact and location in question ${ }^{28}$. According to physical understanding, for instance, warming implies glacier shrinkage and thus changes in the contribution of ice melt to river runoff ${ }^{52,53}$ or formation and growth of glacier lakes with possible lake outburst floods and associated risks ${ }^{54,55}$. As another example, given the sensitivity of crops such as grapes or coffee to changes in temperature, precipitation, and soil moisture ${ }^{56-58}$ we can expect that yield, quality, phenology, pest and disease, planting site suitability and possibly supply chains may be affected $^{59-62}$. However, our understanding will be limited with respect to the exact magnitude of these impacts, especially along cascades of impacts from crop production to food supply. Further challenges arise from ongoing adaptation in human and managed systems, in particular for agricultural systems as demonstrated in recent studies ${ }^{63,64}$. Thus, while we suggest that understanding of general causation could serve the reconciliation processes, the value and limitations of this sort of evidence may vary among different types of impacts and is not likely to be sufficient to attain justice in the full sense. In climate policy, as the Paris negotiations have shown, many countries do in fact recognize some moral responsibility for impacts of climate change, but are reluctant to define any legal implications thereof in more detail. Against this background, we believe that explicit recognition of moral responsibilities for climate change impacts plays a significant role in fostering cooperation among the Parties to the UNFCCC.

\section{The ability to assist principle and risk management}

Discourses on global justice provide the grounds for a second alternative beyond liabilities and compensation. A number of scholars offer arguments to distinguish between responsibilities to assist and claims for compensation from those liable for harm ${ }^{65-68}$. Ability to assist (AAP) is in line with the APP (see Textbox 1) and assumes an assignment of responsibilities proportional to economic, technological and logistic capacities. With regard to climate change impacts specifically, we argue that prioritizing the ability to assist is supported in the following contexts ${ }^{15,67,69}$ : when a projected 
climate impact is severe and immediate help is needed; when there is missing clarity on whether the party causing a negative impact did something morally wrong; or when the party responsible for the impact is not able to provide full recovery. It is important to note that prioritizing AAP does not mean that PPP and BPP should be dismissed altogether. Rather we think that AAP is more plausible and feasible in the aforementioned contexts than the other justice principles. In the context of climate change impacts, we suggest that AAP includes an ex-ante component to facilitate prevention of and preparedness for L\&D. Many different mechanisms exist to meet responsibilities to assist in the aforementioned sense and context, including reconstruction, programs to strengthen preparedness and institutions responsible for risk management, or technology transfer. Most of these mechanisms can be accommodated under the perspective of integrative risk management ${ }^{70}$.

Appropriate identification and understanding of risks, and how risks change over time, is an important prerequisite for risk management. In the IPCC AR5 risk is defined as a function of (climate) hazard, exposure of assets and people, and their vulnerability ${ }^{71}$. For the climate hazard component of risks, extreme weather events are a primary concern. A large number of studies have identified observed trends in extreme weather, both globally ${ }^{72-74}$ and regionally ${ }^{75,76}$, and have examined their relation to anthropogenic climate change ${ }^{77,78}$. Particularly challenging and debated is the attribution of single extreme weather events to anthropogenic climate change ${ }^{8,77,79-81}$. On the other hand, disaster risk studies focusing on L\&D due to extreme weather events generally have concluded that the observed strong increase in monetary losses is primarily due to changes in exposure and wealth ${ }^{82-84}$, with a dynamic contribution from vulnerability ${ }^{85}$. For instance, for detected changes in heat related human mortality, changes in exposure, health care or physical infrastructure and adaptation are important drivers and often outweigh the effects of climate change ${ }^{86-89}$. Risk management yet should not only be concerned with impacts of extreme weather events but also with negative effects of gradual climate change on natural, human and managed systems. Based on the assessment of the IPCC AR5, concern for unique and threatened systems has mounted for Arctic, marine and mountain systems, including Arctic marine ecosystems, glaciers and permafrost, and Arctic indigenous livelihoods ${ }^{6}$. Impacts of gradual climate change are often exacerbated by extreme events, thus enhancing risks and complicating attribution ${ }^{90}$. Furthermore, impacts of climate change usually occur within a context of multiple non-climatic drivers of risk. Effective identification of specific activities to reduce risk may require estimation of the relative balance of the contributions of climatic and non-climatic drivers. However, understanding of general causation, in the form for instance of process-based understanding, may not provide sufficient precision to distinguish the relative importance of the various drivers; in that case, more refined information generated through 
detection and attribution analysis may be required. This, however, implies the availability of longterm data which is limited in many developing countries.

In the context of international climate policy, assistance provided to strengthen risk management is largely uncontested and is supported in many documents ${ }^{91}$. Hence, political feasibility, the justice basis and potential progress in scientific evidence make risk management a promising vehicle for addressing climate change impacts.

\section{Injustices from the imbalance of climate and impact monitoring}

Depending on the approaches outlined in the previous sections, observational monitoring of climate and impacts can be of fundamental importance in order to provide the necessary causal evidence, and to satisfy justice claims posed by many Parties. In this light, it is informative to consider the distribution of long-term climate observations, as well as that of the detected and attributed impacts as assessed by the IPCC AR5 ${ }^{6}$. As Figure 2 shows, the distribution of both long-term recording weather stations and observed impacts of climate change is unequal across the globe. Observations of non-climatic factors, which are important to assess the magnitude of impacts of climatic versus non-climatic factors, are not shown in Figure 2 but are likely to show a similar imbalanced pattern. The analysis of attributed impacts based on IPCC AR5 ${ }^{6}$ reveals that more than $60 \%$ of the attributed impacts considered come from the 43 Annex I countries while the 154 Non-Annex I countries feature less than $40 \%$ of the observations (Fig. 3). This imbalance is even larger if the least developed countries (LDC) and the countries of the Small Island Developing States (SIDS) (80 countries together) are considered, for which less than $20 \%$ of globally detected and attributed impacts are reported. While different identified impacts in the IPCC AR5 reflect different degrees of aggregation (e.g. aggregating phenological shifts across species on a continent into a single impact unit), this aggregation tends to be amplified in Annex I countries, and thus understates the geographical contrast in terms of available evidence between developed and developing countries. Additionally, Non-Annex I, LDC and SIDS countries generally have a higher proportion of impacts with very low and low confidence in attribution to climate change whereas Annex I countries have more impacts with high confidence in attribution. The assignment of confidence thereby typically relates, among other things, to the quality and duration of available observational series ${ }^{92-94}$; this also holds for the attribution of observed climate trends to greenhouse gas emissions ${ }^{95}$. This imbalance thus reflects an unequal distribution of monitoring for physical as well as for biological, managed and human systems. 
The results of this analysis imply new kinds of injustices involved in the approaches discussed above. Whichever approach is chosen, the unequal distribution of observed and attributed impacts, and of the confidence in assessments, implies an unjustified disadvantage for those most in need of assistance. The more impacts are detected and their attribution to climate change is clarified the better it is understood (i) what responsibilities would have to be recognized, (ii) what the appropriate measures of risk management might be, and (iii) what would represent appropriate methods of compensation for negative climate change effects on natural and human systems. In this respect many Non-Annex I countries seem to be disadvantaged as compared to Annex I countries. This disadvantage represents a form of procedural injustice in negotiating and deciding when, where and what measures are taken. Hence, the point here is not the potentially unfair outcomes of negotiations but the fairness of the process of negotiating itself. The imbalance of the distribution of detected and attributed impacts was in fact an issue during the final IPCC AR5 government approval process ${ }^{96}$, indicating concern that voices from some actors and parties might be downplayed or ignored due to lack of hard evidence for perceived impacts.

Against this background, we argue in line with a version of the APP (AAP) that countries with appropriate economic, technological and logistic capacities should enhance the support for countries with limited available resources or capacity along two lines of actions and policy: i) to substantially improve monitoring of a broad range of climate change impacts on natural and human systems; ii) to strengthen local human resources and capacities in countries facing important climate change impacts to a level that ensures an adequate quality and extent of monitoring and scientific analysis. This proposal is perfectly in line with the UNFCCC and decisions taken at recent negotiations including COP21 ${ }^{1,91}$, and actions and programs underway in several Non-Annex I countries, hence strongly increasing its political feasibility. The lack of monitoring and observations has been long recognized but the related procedural injustice has not received much discussion. Our analysis intends to provide the justice basis and context to justify strengthening these efforts. However, even if such efforts are substantially developed in the near future, a major challenge remains in how to cope with non-existing or low-quality observational records of the past decades in countries were no corresponding monitoring had been in place. Reconstruction of past climate change impacts and events exploiting historical satellite data, on-site field mapping, searching historical archives, etc. may be able to recover missing data to some extent. Different and diverse forms of knowledge existing in various regions and localities can be of additional value but need to be evaluated in their respective context to avoid simplistic comparisons of, for instance, scientific versus local knowledge ${ }^{97}$. Substantial observational limitations, however, will likely remain and the implications for the aforementioned approaches toward justice need to be seriously considered. 
In this Perspective we discussed different approaches towards justice regarding negative climate change impacts. We argued that depending on the approach chosen, different kinds of evidence concerning detection and attribution of climate change impacts are needed. Establishing liabilities in a legal or political context to seek compensation sets the highest bar, and we suggest that it requires detection and attribution in line with specific causation. However, in general the level of scientific evidence currently available rarely supports high confidence in linking impacts to emissions, except for some natural and human systems related to the mountain and Arctic cryosphere and the health of warm water corals. Hence, claims for compensation based on liabilities will likely continue to encounter scientific hurdles, in addition to various political and legal hurdles. Understanding the role of climate change in trends in impacted natural and human systems at a level of evidence currently available can still effectively inform other justice principles which in our view are politically much more feasible, namely recognition of responsibilities and ability to assist. Attribution research can clarify responsibilities and thus facilitate their recognition; and it can enhance the understanding of drivers of risks as a basis for improved risk management. More rigorous implementation of risk management is actually critical to prevent and reduce future L\&D. Whether recognition of responsibilities and APP / AAP are politically sufficient to facilitate ex-ante compensation, for instance with the creation of a monetary fund for current or future victims of climate change impacts, needs yet to be seen. Finally, the imbalance of observed and attributed climate change impacts leaves those countries most in need of assistance (i.e. SIDS and LDC countries) with relatively poor evidence in support of appropriate risk management approaches or any claim for liability and related compensation in international climate policy or at courts. We have argued that evidence in line with general causation may be sufficient for recognition of responsibilities, and hence, this may well speak in favor of this justice approach, considering the aforementioned limitations in observations and attribution. Recognition of responsibilities cannot represent the final step to attain justice, however, and we therefore suggest that two issues remain crucial: i) procedural injustice resulting from an imbalance of detected and attributed impacts should be considered as a fundamental issue in negotiations and decision making in international climate policy; and ii) monitoring of climate change impacts in natural and human systems, and local capacities in developing countries need to be substantially strengthened. Efforts taken now will be of critical value for the future when climate change impacts are expected to be more severe than experienced so far. 


\section{Author contributions}

2 C.H. and I.W.-H. designed the basic concept and arguments of the paper, supported and advised by

3 D.S. and W.C. C.H. and D.S. analysed the impacts data and prepared the figures. All authors

4 contributed to the writing of the text.

5

6

\section{Acknowledgements}

8 C. H. was supported by strategic funds by the Executive Board and Faculty of Science of the

9 University of Zurich. I. W.-H. acknowledges financial support by the Stiftung Mercator Switzerland and the University of Zurich's Research Priority Program for Ethics (URPP Ethics). D.S. was supported by the US Department of Energy Office of Science, Office of Biological and Environmental Research, under contract number DE-AC02-05CH11231. W.C. contributes to the Labex OT-Med (no. ANR-11LABX-0061) funded by the French Government through the A*MIDEX project (no. ANR-11-IDEX-000102). We furthermore appreciate the collaboration with Gerrit Hansen on the analysis of the distribution of climate change impacts. 


\section{References}

1. UNFCCC. Adoption of the Paris Agreement. (United Nations Framework Convention on Climate Change (UNFCCC), UNFCCC/CP/2015/L.9/Rev.1, 2015).

2. Warner, K. \& van der Geest, K. Loss and damage from climate change: local-level evidence from nine vulnerable countries. Int. J. Glob. Warm. 5, 367-386 (2013).

3. Okereke, C., Baral, P. \& Dagnet, Y. in Working Paper 19 pp. (Agreement for Climate Transformation 2015 (ACT15), 2014).

4. Burkett, M. Climate Reparations. Melb. J. Int. Law 10, 34 (2009).

5. Rosenzweig, C. \& Neofotis, P. Detection and attribution of anthropogenic climate change impacts. Wiley Interdiscip. Rev. Clim. Change 4, 121-150 (2013).

6. Cramer, W. et al. in Climate Change 2014: Impacts, Adaptation, and Vulnerability. Part A: Global and Sectoral Aspects. Contribution of Working Group II to the Fifth Assessment Report of the Intergovernmental Panel of Climate Change (eds. Field, C. B. et al.) 979-1037 (Cambridge University Press, 2014).

7. Hansen, G. \& Stone, D. Assessing the observed impact of anthropogenic climate change. Nat. Clim. Change advance online publication, (2015).

8. National Academies of Sciences, Engineering, and Medicine. Attribution of extreme weather events in the context of climate change. 144 (Washington, DC: The National Academies Press, 2016).

9. Huggel, C., Stone, D., Auffhammer, M. \& Hansen, G. Loss and damage attribution. Nat. Clim. Change 3, 694-696 (2013).

10. Allen, M. R. \& Lord, R. The blame game. Nature 432, 551-552 (2004).

11. Pall, P. et al. Anthropogenic greenhouse gas contribution to flood risk in England and Wales in autumn 2000. Nature 470, 382-385 (2011).

12. Hulme, M. Attributing weather extremes to 'climate change' A review. Prog. Phys. Geogr. 499-511 (2014). doi:10.1177/0309133314538644 
1 13. James, R. et al. Characterizing loss and damage from climate change. Nat. Clim. Change 4, $2 \quad 938-939(2014)$.

3 14. Thompson, A. \& Otto, F. E. L. Ethical and normative implications of weather event attribution 4 for policy discussions concerning loss and damage. Clim. Change 133, 439-451 (2015).

15. Wallimann-Helmer, I. Justice for climate loss and damage. Clim. Change 133, 469-480 (2015).

16. Hayward, T. Climate change and ethics. Nat. Clim. Change 2, 843-848 (2012).

17. Hart, H. L. A. \& Honoré, T. Causation in the law. (Clarendon Press, 2002).

18. Honoré, A. in Stanford Encyclopedia of Philosophy (ed. Zalta, E. N.) (2014).

19. McKinnon, C. Climate justice in a carbon budget. Clim. Change 1-10 (2015). doi:10.1007/s10584-015-1382-6

20. Pachauri, R. K., Gardiner, S., Caney, S., Jamieson, D. \& Shue, H. Climate ethics: Essential readings. (Oxford University Press, 2010).

21. Page, E. Distributing the Burdens of Climate Change. Environ. Polit. 17, 556-575 (2008).

22. Gardiner, S. M. Ethics and Global Climate Change. Ethics 114, 555-600 (2004).

23. Shue, H. Global Environment and International Inequality. Int. Aff. 75, 531-545 (1999).

24. Halme, P. Carbon Debt and the (In)significance of History. Trames 11, 346-365 (2007).

25. Gosseries, A. Historical Emissions and Free-Riding. Ethical Perspect. 11, 36-60 (2004).

26. Baatz, C. Responsibility for the Past? Some Thoughts on Compensating Those Vulnerable to Climate Change in Developing Countries. Ethics Policy Environ. 16, 94-110 (2013).

27. Caney, S. Cosmopolitan Justice, Responsibility, and Global Climate Change. Leiden J. Int. Law 18, 747-775 (2005).

28. Huggel, C., Stone, D., Eicken, H. \& Hansen, G. Potential and limitations of the attribution of climate change impacts for informing loss and damage discussions and policies. Clim. Change 1-15 (2015). doi:10.1007/s10584-015-1441-z

29. Schleiter, K. E. Proving Causation in Environmental Litigation. Virtual Mentor 11, 456 (2009). 
$130 . \quad$ Stone, D. et al. The challenge to detect and attribute effects of climate change on human and 2 natural systems. Clim. Change 121, 381-395 (2013).

3 31. Goodin, R. E. Theories of Compensation. Oxf. J. Leg. Stud. 9, 56-75 (1989).

32. Miller, D. Global justice and climate change: How should responsibilities be distributed. Tann. Lect. Hum. Values 28, 1-128 (2008).

33. Pogge, T. World poverty and human rights: Cosmopolitan responsibilities and reforms. (Polity,

7 2009).

34. Verheyen, R. \& Roderick, P. Beyond Adaptation-The legal duty to pay compensation for climate change damage. 38 (WWF-UK, 2008).

35. Hansen, G., Stone, D., Auffhammer, M., Huggel, C. \& Cramer, W. Linking local impacts to changes in climate: a guide to attribution. Reg. Environ. Change 1-15 (2015). doi:10.1007/s10113015-0760-y

36. Peel, J. \& Osofsky, H. M. Climate Change Litigation. 116, (Cambridge University Press, 2015).

37. Markell, D. \& Ruhl, J. B. An Empirical Assessment of Climate Change In The Courts: A New Jurisprudence Or Business As Usual? Fla. Law Rev. 64, 15 (2012).

38. Wilensky, M. Climate change in the courts: an assessment of non-U.S. climate litigation. Columbia Law Sch. Sabin Cent. Clim. Change Law 52 (2015).

39. Mclnerney-Lankford, S., Darrow, M. \& Rajamani, L. Human Rights and Climate Change: A Review of the International Legal Dimensions. (World Bank Publications, 2011).

40. Posner, E. A. Climate Change and International Human Rights Litigation: A Critical Appraisal. (Social Science Research Network, 2007).

41. Farber, D. A. Basic Compensation for Victims of Climate Change. Univ. Pa. Law Rev. 155, 1605-1656 (2007).

42. Weisbach, D. A. Negligence, strict liability, and responsibility for climate change. lowa Law Rev. 97, 521-565 (2012). 
1 43. Maldonado, J. K., Shearer, C., Bronen, R., Peterson, K. \& Lazrus, H. The impact of climate 2 change on tribal communities in the US: displacement, relocation, and human rights. Clim. Change $3 \quad 120,601-614(2013)$.

44. Grossman, D. A. in Adjudicating climate change: state, national, and international approaches. W.C.G. Burns and H.M. Osofsky (eds.) 193-229 (Cambridge University Press, 2009).

45. May, L. Reparations, Restitution, and Transitional Justice. Moral. Jus Post Bellum Int. Law 3248 (2012).

46. Roberts, R. C. in Encyclopedia of Global Justice (ed. Chatterjee, D. K.) 936-938 (Springer Netherlands, 2011).

47. Eisikovits, N. in Stanford Encyclopedia of Philosophy (ed. Zalta, E. N.) (2014).

48. Bell, D. R. Environmental Refugees: What Rights? Which Duties? Res Publica 10, 135-152 (2004).

49. Byravan, S. \& Rajan, S. C. The Ethical Implications of Sea-Level Rise Due to Climate Change. Ethics Int. Aff. 24, 239-260 (2010).

50. Heyward, C. in New Waves in Global Justice (ed. Brooks, T.) 149-169 (2014).

51. Zellentin, A. Climate justice, small island developing states \& cultural loss. Clim. Change (2015).

52. Kaser, G., Grosshauser, M. \& Marzeion, B. Contribution potential of glaciers to water availability in different climate regimes. Proc. Natl. Acad. Sci. 107, 223-227 (2010).

53. Schaner, N., Voisin, N., Nijssen, B. \& Lettenmaier, D. P. The contribution of glacier melt to streamflow. Environ. Res. Lett. 7, 34029 (2012).

54. Iribarren Anacona, P., Mackintosh, A. \& Norton, K. P. Hazardous processes and events from glacier and permafrost areas: lessons from the Chilean and Argentinean Andes. Earth Surf. 
$1 \quad$ 55. Allen, S. K., Rastner, P., Arora, M., Huggel, C. \& Stoffel, M. Lake outburst and debris flow

2 disaster at Kedarnath, June 2013: hydrometeorological triggering and topographic predisposition.

3 Landslides 1-13 (2015). doi:10.1007/s10346-015-0584-3

4 56. Jaramillo, J. et al. Climate Change or Urbanization? Impacts on a Traditional Coffee

5 Production System in East Africa over the Last 80 Years. PLoS ONE 8, e51815 (2013).

6 57. Hannah, L. et al. Climate change, wine, and conservation. Proc. Natl. Acad. Sci. 110, 6907-

$76912(2013)$

8 58. Moriondo, M. et al. Projected shifts of wine regions in response to climate change. Clim.

Change 119, 825-839 (2013).

59. Laderach, P. et al. in The Economic, Social and Political Elements of Climate Change (ed. Filho, W. L.) 703-723 (Springer Berlin Heidelberg, 2011).

60. Holland, T. \& Smit, B. Climate Change and the Wine Industry: Current Research Themes and New Directions. J. Wine Res. 21, 125-136 (2010).

61. Webb, L. B. et al. Earlier wine-grape ripening driven by climatic warming and drying and management practices. Nat. Clim. Change 2, 259-264 (2012).

62. Baca, M., Läderach, P., Haggar, J., Schroth, G. \& Ovalle, O. An Integrated Framework for Assessing Vulnerability to Climate Change and Developing Adaptation Strategies for Coffee Growing Families in Mesoamerica. PLoS ONE 9, e88463 (2014).

63. Lobell, D. B. Climate change adaptation in crop production: Beware of illusions. Glob. Food Secur. 3, 72-76 (2014).

64. Lereboullet, A.-L., Beltrando, G. \& Bardsley, D. K. Socio-ecological adaptation to climate change: A comparative case study from the Mediterranean wine industry in France and Australia. Agric. Ecosyst. Environ. 164, 273-285 (2013).

65. Miller, D. Holding Nations Responsible. Ethics 114, 240-268 (2004).

66. Young, I. M. Responsiblity and Global Justice: A Social Connection Model. Soc. Philos. Policy 23, 102-130 (2006). 
1 67. Jagers, S. C. \& Duus-Otterström, G. Dual climate change responsibility: on moral divergences 2 between mitigation and adaptation. Environ. Polit. 17, 576-591 (2008).

3 68. Miller, D. National Responsibility and Global Justice. (Oxford University Press, 2007).

69. Wallimann-Helmer, I. in Philosophy, Law and Environmental Crisis / Philosophie, droit et crise environnementale (eds. Papaux, A. \& Zurbuchen, Y.) 119-132 (2016).

70. Mechler, R. et al. Managing unnatural disaster risk from climate extremes. Nat. Clim. Change 4, 235-237 (2014).

71. Oppenheimer, M. et al. in Climate Change 2014: Impacts, Adaptation, and Vulnerability. Part A: Global and Sectoral Aspects. Contribution of Working Group II to the Fifth Assessment Report of the Intergovernmental Panel of Climate Change (eds. Field, C. B. et al.) 1039-1099 (Cambridge University Press, 2014).

72. Hansen, J., Sato, M. \& Ruedy, R. Perception of climate change. Proc. Natl. Acad. Sci. 109, E2415-E2423 (2012).

73. Hartmann, D. L., A. M. G.Klein Tank, M.Rusticucci, L. V.Alexander, S.Brönnimann, Y.Charabi, F. J.Dentener, E. J.Dlugokencky, D. R.Easterling, A.Kaplan, B. J.Soden, P. W.Thorne, M.Wild and P. M.Zhai. in Climate Change 2013: The Physical Science Basis. Contribution of Working Group I to the Fifth Assessment Report of the Intergovernmental Panel on Climate Change (ed. Stocker, T. F., D.Qin, G. K.Plattner, M.Tignor, S. K.Allen, J.Boschung, A.Nauels, Y.Xia, V.Bex and P. M.Midgley) 159-254 (Cambridge University Press, 2013).

74. Westra, S., Alexander, L. V. \& Zwiers, F. W. Global Increasing Trends in Annual Maximum Daily Precipitation. J. Clim. 26, 3904-3918 (2012).

75. Skansi, M. de los M. et al. Warming and wetting signals emerging from analysis of changes in climate extreme indices over South America. Glob. Planet. Change 100, 295-307 (2013). since 1871. Geophys. Res. Lett. 38, (2011). 
1 77. Bindoff, N. L., P. A.Stott, K. M.AchutaRao, M. R.Allen, N.Gillett, D.Gutzler, K.Hansingo,

2 G.Hegerl, Y.Hu, S.Jain, I. I.Mokhov, J.Overland, J.Perlwitz, R.Sebbari and X.Zhang. in Climate Change 2013: The Physical Science Basis. Contribution of Working Group I to the Fifth Assessment Report of the Intergovernmental Panel on Climate Change (ed. Stocker, T. F., D.Qin, G. K.Plattner, M.Tignor, S. K.Allen, J.Boschung, A.Nauels, Y.Xia, V.Bex and P. M.Midgley) 867-952 (Cambridge University Press, 2013).

78. Otto, F. E. L. et al. Attribution of extreme weather events in Africa: a preliminary exploration of the science and policy implications. Clim. Change 132, 531-543 (2015).

79. Otto, F. E. L., Massey, N., Oldenborgh, G. J. van, Jones, R. G. \& Allen, M. R. Reconciling two approaches to attribution of the 2010 Russian heat wave. Geophys. Res. Lett. 39, 5 PP. (2012).

80. Trenberth, K. E., Fasullo, J. T. \& Shepherd, T. G. Attribution of climate extreme events. Nat. Clim. Change 5, 725-730 (2015).

81. Seneviratne, S. I. et al. in Managing the Risks of Extreme Events and Disasters to Advance Climate Change Adaptation. A Special Report of Working Groups I and II of the Intergovernmental Panel on Climate Change (IPCC) (eds. Field, C. B. et al.) 109-230 (Cambridge University Press, 2012).

82. Bouwer, L. M. Have Disaster Losses Increased Due to Anthropogenic Climate Change? Bull. Am. Meteorol. Soc. 92, 39-46 (2011).

83. Barthel, F. \& Neumayer, E. A trend analysis of normalized insured damage from natural disasters. Clim. Change 113, 215-237 (2012).

84. IPCC. Managing the Risks of Extreme Events and Disasters to Advance Climate Change Adaptation. A Special Report of Working Groups I and II of the Intergovernmental Panel on Climate Change [Field, C.B., V. Barros, T.F. Stocker, D. Qin, D.J. Dokken, K.L. Ebi, M.D. Mastrandrea, K.J. Mach, G.-K. Plattner, S.K. Allen, M. Tignor, and P.M. Midgley (eds.)]. (Cambridge University Press, 2012). 
85. Mechler, R. \& Bouwer, L. M. Understanding trends and projections of disaster losses and climate change: is vulnerability the missing link? Clim. Change 133, 23-35 (2015).

86. Christidis, N., Donaldson, G. C. \& Stott, P. A. Causes for the recent changes in cold- and heatrelated mortality in England and Wales. Clim. Change 102, 539-553 (2010).

87. Oudin Åström, D., Forsberg, B., Ebi, K. L. \& Rocklöv, J. Attributing mortality from extreme temperatures to climate change in Stockholm, Sweden. Nat. Clim. Change 3, 1050-1054 (2013).

88. Arent, D. J. et al. in Climate Change 2014: Impacts, Adaptation, and Vulnerability. Part A: Global and Sectoral Aspects. Contribution of Working Group II to the Fifth Assessment Report of the Intergovernmental Panel of Climate Change (eds. Field, C. B. et al.) XXX-YYY (Cambridge University Press, 2014).

89. Smith, K. R. et al. in Climate Change 2014: Impacts, Adaptation, and Vulnerability. Part A: Global and Sectoral Aspects. Contribution of Working Group II to the Fifth Assessment Report of the Intergovernmental Panel of Climate Change (eds. Field, C. B. et al.) 709-754 (Cambridge University Press, 2014).

90. Huggel, C., Stone, D., Eicken, H. \& Hansen, G. Potential and limitations of the attribution of climate change impacts for informing loss and damage discussions and policies. Clim. Change 133, 453-467 (2015).

91. UNFCCC. Lima Call for Climate Action. Report of the Conference of the Parties on its twentieth session, held in Lima from 1 to 14 December 2014. (United Nations Framework Convention on Climate Change (UNFCCC), UNFCCC/CP/2014/10/Add.1, 2015).

92. Hegerl, G. et al. Good practice guidance paper on detection and attribution related to anthropogenic climate change. in (2010).

93. Adler, C. E. \& Hirsch Hadorn, G. The IPCC and treatment of uncertainties: topics and sources of dissensus. Wiley Interdiscip. Rev. Clim. Change 5, 663-676 (2014).

94. Ebi, K. L. Differentiating theory from evidence in determining confidence in an assessment finding. Clim. Change 108, 693-700 (2011). 
$195 . \quad$ Stone, D. A. \& Hansen, G. Rapid systematic assessment of the detection and attribution of

2 regional anthropogenic climate change. Clim. Dyn. 1-17 (2015). doi:10.1007/s00382-015-2909-2

3 96. Hansen, G. \& Cramer, W. Global distribution of observed climate change impacts. Nat. Clim.

$4 \quad$ Change 5, 182-185 (2015).

$597 . \quad$ Reyes-García, V. et al. Local indicators of climate change: the potential contribution of local

6 knowledge to climate research. Wiley Interdiscip. Rev. Clim. Change n/a-n/a (2015).

$7 \quad$ doi:10.1002/wcc.374

8 98. Hansen, J., Ruedy, R., Sato, M. \& Lo, K. Global Surface Temperature Change. Rev. Geophys.

48, RG4004 (2010).

99. Donat, M. G. et al. Updated analyses of temperature and precipitation extreme indices since the beginning of the twentieth century: The HadEX2 dataset. J. Geophys. Res. Atmospheres 118, 2098-2118 (2013).

100. Rayner, N. A. et al. Global analyses of sea surface temperature, sea ice, and night marine air temperature since the late nineteenth century. J. Geophys. Res. Atmospheres 108, 4407 (2003). 


\section{Figure captions}

Figure 1: A schematic detection and attribution framework for impacts on natural and human systems. The left part (in light grey) indicates the different impacts and the respective level of confidence in detection and attribution of a climate change influence as assessed in the IPCC Working Group II $5^{\text {th }}$ Assessment Report (AR5) ${ }^{6}$. Boxes with a thick (thin) outline indicate a major (minor) role of climate change as assessed in $\left.{ }^{6}\right]$ (note that this IPCC assessment ${ }^{6}$ did not distinguish between natural and anthropogenic climate change in relation with impacts). The right part (in darker grey) of the figure identifies important climatic and non-climatic drivers of detected impacts at global scales. The attribution statements for the climatic drivers are from IPCC WGI AR5 ${ }^{77}$ and refer to anthropogenic climate change. Trends in the graphs are all for global drivers and represent from top to bottom the following: TAS: mean annual land air temperature ${ }^{98}$; TXX (TNn): hottest (coldest) daily maximum (minimum) temperature of the year ${ }^{99}$; TOS sea surface temperature ${ }^{100}$ (all units are degrees Celsius and anomalies from the 1981-2010 global average); SIC: northern hemisphere sea ice coverage ${ }^{100}$ (in million $\mathrm{km}^{2}$ ); Popul: total world population (in billions); GDP: global gross domestic product (in 2005 USD); Life exp. and health expend.: total life expectancy at birth and public health expenditure (\% of GDP) (Data sources: The World Bank ,World Bank Open Data, http://data.worldbank.org/).

Figure 2: World map showing the distribution of Global Historical Climatology Network (GHCN) stations and the number of detected impacts as assessed in the IPCC WGII AR5 ${ }^{6}$. It distinguishes between Annex I countries (in red colors), Non-Annex I countries (in green colors), and regions not party to the UNFCCC (grey colors). The GHCN is the largest publicly available collection of global surface air temperature station data. The shaded regions correspond to the regional extent of relevant climatic changes for various impacts, rather than of the impacts themselves, as determined in $\left[^{7}\right]$; a few impacts are not included due to insufficient information for defining a relevant region.

Figure 3: Distribution of attributed climate change impacts in physical, biological and human systems as assessed in the IPCC WGII AR5 ${ }^{6}$, showing an imbalance between Annex I, Non-Annex I, and Least Developed Countries (LDC) and Small Island Development States (SIDS). Three confidence levels of attribution are distinguished. Note that LDC and SIDS are also part of Non-Annex I countries. 


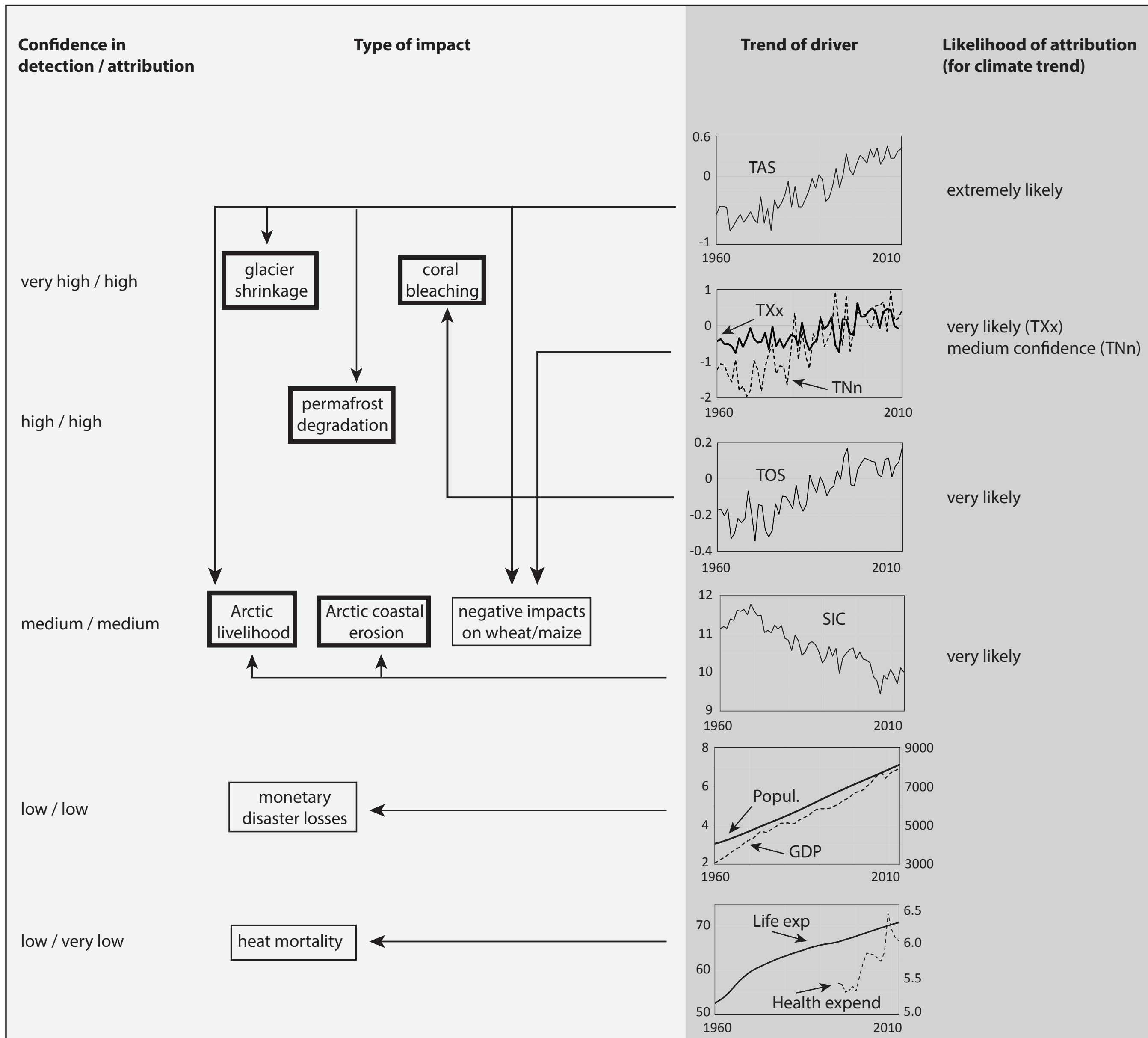




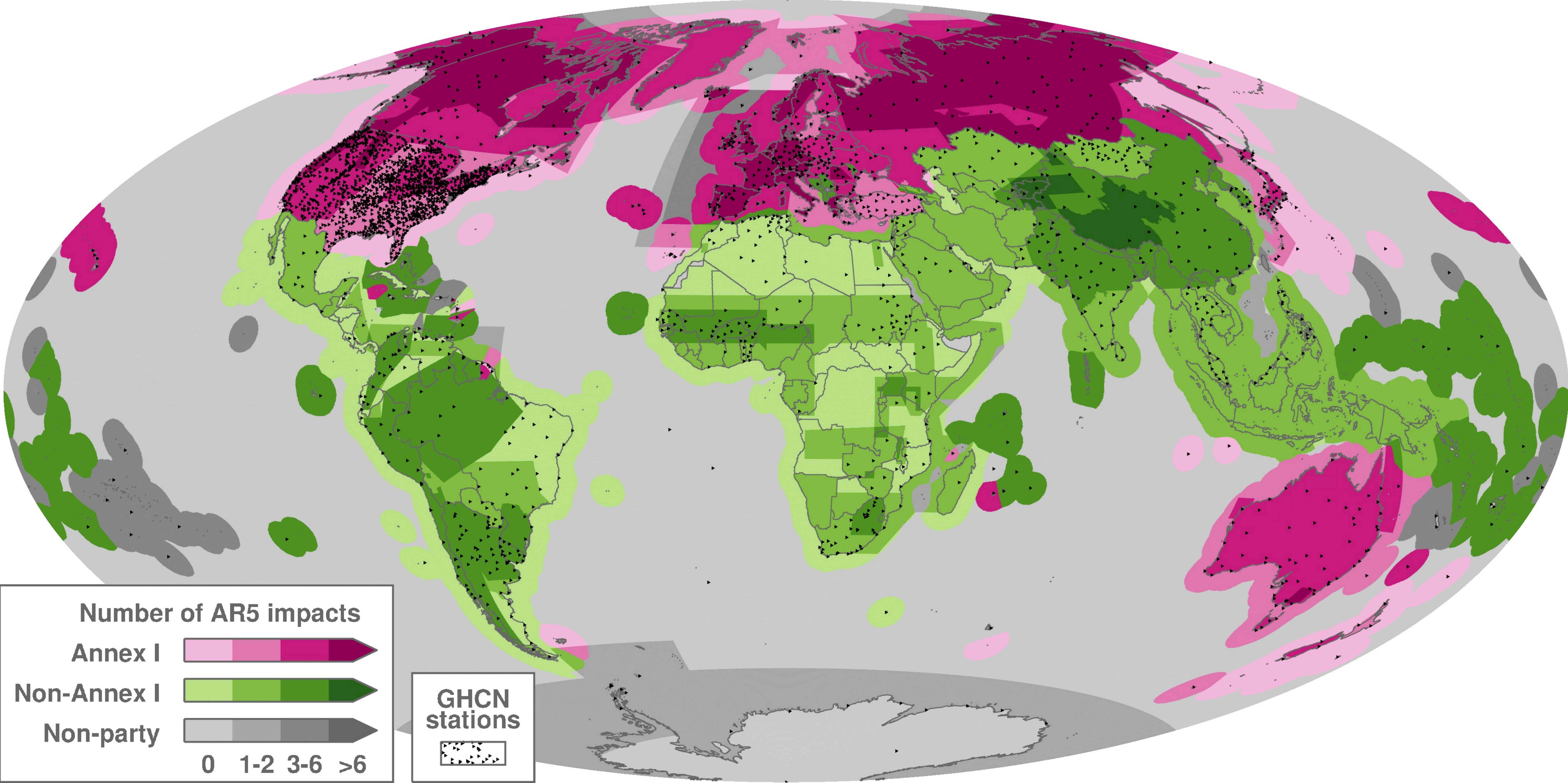




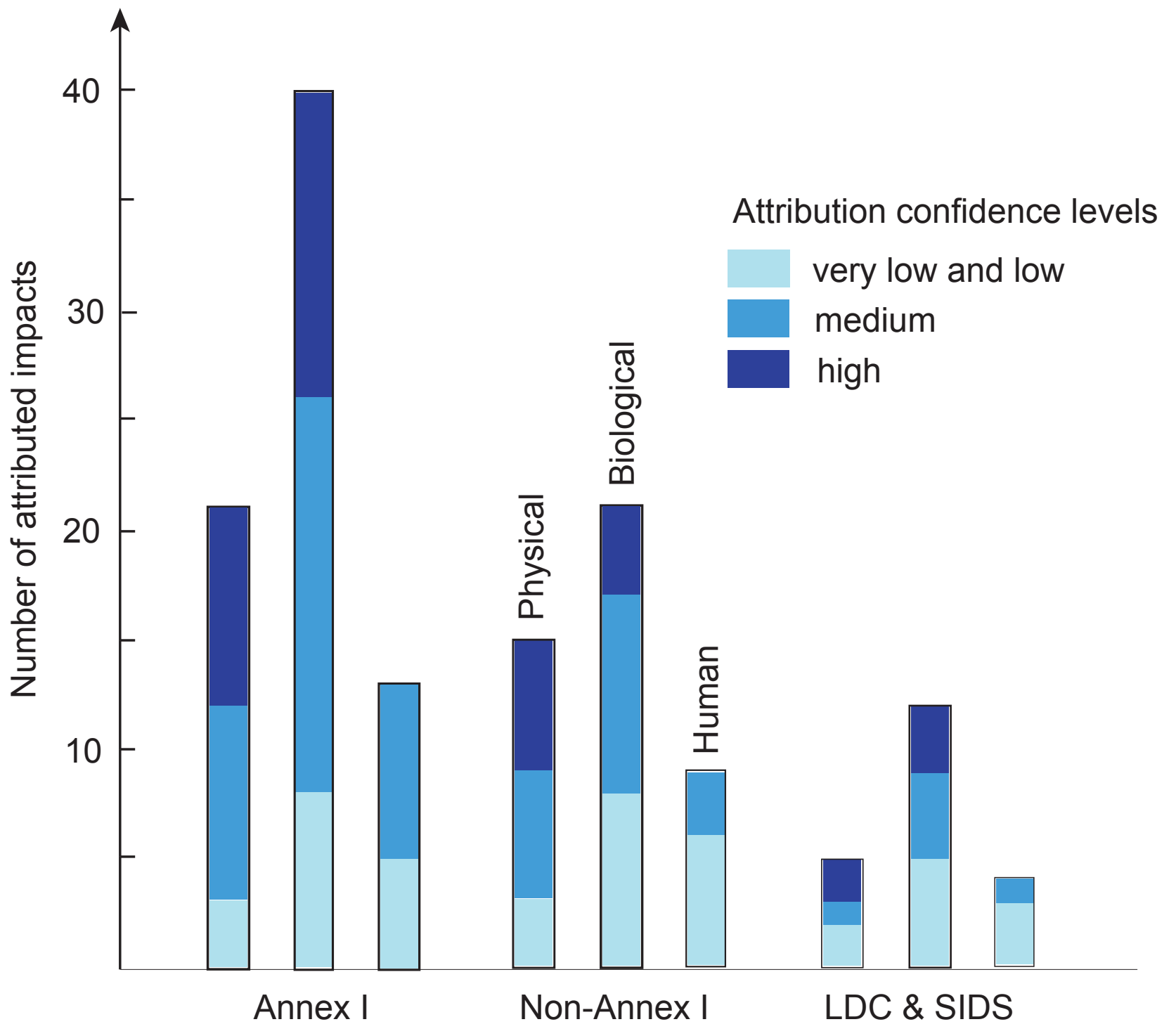

